\title{
Resilience and Urban Regeneration Policies. Lessons from Community-Led Initiatives. The Case Study of CanFugarolas in Mataro (Barcelona)
}

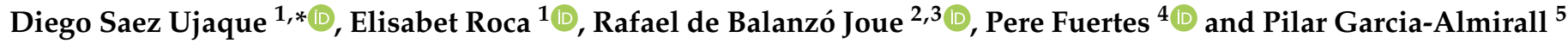 \\ 1 Institute for Sustainability Science and Technology, Universitat Politecnica de Catalunya, 08028 Barcelona, \\ Spain; elisabet.roca@upc.edu \\ 2 Queens College, City University of New York, New York, NY 11367, USA; rbalanzoj@gmail.com \\ 3 EINA, School of Design and Art, Universitat Autònoma de Barcelona, 08017 Barcelona, Spain \\ 4 Department of Architectural Design, Universitat Politecnica de Catalunya, 08028 Barcelona, Spain; \\ pere.fuertes@upc.edu \\ 5 Department of Architectural Technology, Universitat Politecnica de Catalunya, 08028 Barcelona, Spain; \\ pilar.garcia-almirall@upc.edu \\ * Correspondence: diego.saez@upc.edu; Tel.: +34-687-496-478
}

Citation: Saez Ujaque, D.; Roca, E.; de Balanzó Joue, R.; Fuertes, P.; Garcia-Almirall, P. Resilience and Urban Regeneration Policies. Lessons from Community-Led Initiatives. The Case Study of CanFugarolas in Mataro (Barcelona). Sustainability 2021, 13, 12855. https://doi.org/ $10.3390 /$ su132212855

\section{Academic Editors:}

Mohammad Swapan, Courtney Babb and Reazul Ahsan

Received: 22 September 2021

Accepted: 18 November 2021

Published: 20 November 2021

Publisher's Note: MDPI stays neutral with regard to jurisdictional claims in published maps and institutional affiliations.

Copyright: (c) 2021 by the authors. Licensee MDPI, Basel, Switzerland. This article is an open access article distributed under the terms and conditions of the Creative Commons Attribution (CC BY) license (https:/ / creativecommons.org/licenses/by/ $4.0 /)$.

\begin{abstract}
This paper addresses socio-ecological, community-led resilience as the ability of the urban system to progress and adapt. This is based on the socio-cultural, self-organized case study of CanFugarolas in Mataró (Barcelona), for the recovery of a derelict industrial building and given the lack of attention to resilience emerging from grassroots. Facing rigidities (stagnation) observed under the provisions of urban regeneration policies (regulatory realm), evidenced in the proliferation of urban voids (infrastructural arena), the social subsystem stands as the enabler of urban progression. Under the heuristics of the Adaptive Cycle and Panarchy, the study embraces Fath's model to analyze the transition along, and the interactions between, the adaptive cycles at each urban subsystem. The mixed method approach reveals the ability of the community to navigate all stages and overcome successive ailments, despite seemingly insurmountable obstacles (traps) at the physical support (built stock) and the regulatory arena (urban planning). Further, cross-scale, social-centered interactions (panarchy) are also traced, becoming the "sink" and the "trigger" of the urban dynamics. The community, in the form of an actor-network, becomes the catalyst (through Remember/Revolt) of urban resilience at the city scale. At a managerial level, this evidences its temporal and spatial complementarity to top-down urban regeneration policies.
\end{abstract}

Keywords: community resilience; social-centered panarchy; self-organization; socio-ecological resilience; urban dynamics; urban regeneration

\section{Introduction}

Urban resilience provides a useful framework with a large potential for the analysis of urban socio-ecological systems (SES). Bottom-up reorganization mechanisms, selforganization and participation can be key factors for building the adaptive capacity of SES [1,2]. However, practical tools to bridge and put urban resilience findings into the realms and practice of urban planning, economy and policy are still needed [3], especially when it comes to bottom-up or alternative initiatives.

The concept of adaptability varies with the system's ability and capacity for selfreorganization [4]. In the urban dimension, Hassler and Kohler [5] highlight the distinction between designed components that structure the action arena, and the self-organizing processes that play out in such an arena [6]. Society emerges as the outcome of heterogeneous relationships between actors and artifacts, making it impossible to determine the social network or system beforehand, which conditions the subsequent analysis and findings [7]. From the spatial perspective, the city is a reciprocal product of the initiatives of actors that 
interact with spatial developments, which are, in turn, products of collective actions. For Boonstra and Boelens, self-organization in urban development consists of initiatives for spatial interventions that originate in civil society itself, via community-based networks of citizens that are autonomous (i.e., beyond the control of government) yet also contribute to development of the urban fabric.

Thus, the urban community designs and shapes future alternatives. The resulting systems are resilient since they successfully transit all stages of growth, development, collapse and reorientation of this cycle. The outcomes of such processes manifest themselves in specific urban forms, patterns (morphological or functional) and physical growth, or by the emergence of new socio-spatial groups resulting from certain geographical settings or characteristics, such as houses, lots and housing blocks [8]. From a socio-political interpretation, social movements are described as self-organizing systems because they have an internal logic that arises spontaneously. Further, Pereira [9] claims that 'Seed Projects' during urbanization processes can bring about innovation and visions for the future, as well as provide the basis for gathering momentum that involves self-organization around new ideas, the creation and mobilization of networks of support and experimentation in protected niches.

However, from the perspective of urban planning and regeneration policies to date, attempts to integrate self-organization have been limited to participatory planning processes, which have produced poor results [7]. Bottom-up reorganization mechanisms are given little value in urban planning as a lever of change that could strengthen urban resilience. Although such planning processes continue to be controlled by the public government, it seems that the public government fails to adapt to the initiatives that emerge from the dynamics of civil society itself [7]. Scott [10] uses the term "command and control pathology" based on the definition of failed top-down management attempts on natural systems [11] at its direct transposition into the world of urban planning as "seeing-like-a-state pathology". This characterizes urban and political planners who do not consider the self-organizing processes that direct the bottom-up movements of human settlements-from housing to cities, through neighborhoods and districts. One of the most well-known examples of this is Haussmann's disposals for the reorganization of Paris, in which only a small number of large-scale front loops (rapid movement of troops to suppress revolts) was considered while the multitude of small, social-led reactions were ignored, leading to the Paris Commune of 1871.

In order to provide evidence of the value of these bottom-up urban regeneration mechanisms, this paper explores the community-led case study of CanFugarolas in Mataró (Barcelona). CanFugarolas consists of a socio-cultural, community-led initiative set up in 2013 based on the recovery of a derelict industrial building, which had previously been used as a vehicle repair workshop. This process exemplified the self-organized, socially-led the response to the stagnation of "planned" urban regeneration processes.

The objective of the paper is to show how grassroots initiatives build or reinforce the adaptive capacity of a city. Hence, we expect to shed light on two aspects of the social dimension: (1) its inherent ability to progress and evolve (navigate), and (2) its function as an enabler of urban dynamism and adaptation, in the face of the system's ailments and traps, characterized by the failure of urban regeneration policies as evidenced in the proliferation of urban gaps. In this light, we highlight the social momentum as the catalyzer and promotor of urban resilience, as it enables the urban system to move on and progress based on its own self-organized adaptive capacity as well as on the social-centered cross-scale interactions taking place within an urban system.

Finally, under the heuristics of the Adaptive Cycle and Panarchy, we propose to embrace Fath's model [12], in terms of successfully navigating the cycle, to provide novel insight to the role played by the socially-led initiatives for urban regeneration and therefore for urban resilience. 


\section{Theoretical Background}

\subsection{Resilience and Panarchy}

The term 'Resilience' was first introduced by Holling (1973) [13] to describe the models of change in the structures of ecological systems. Natural systems show the existence of multiple domains of stability or multiple basins of attraction. At first, resilience was defined as the ability to stay within a certain domain of attraction to change. It was stated that resilience determines the persistence of relationships within the system and that it is a measure of the ability of these systems to absorb changes to the variables and parameters of the system itself and to persist (Engineering Resilience).

Resilience of Socio-Ecological Systems (SES) has to do with the capacity for change, renewal, reorganization, and development, fundamental for the discourse of sustainability [14]. The adaptive management process was one of the results of this new way of understanding socio-ecological systems. For the first time, "Adaptive Cycle" was defined, where nonlinearities are essential, multi-stable states are inevitable, and the surprise is the consequence of the interaction of processes at different time and space scales [15]. These processes or systems are characterized by the capacity for self-organization, diversity, and the individuality of its components, interaction between components, and the autonomous processes capable of selecting some of the results of these processes for the feedback of the system itself [16]. The resilient perspective implied a leap in the policies to control changes in supposedly stable systems. This made it possible to manage the capacity of socio-ecological systems to cope, adapt and shape change $[17,18]$. In this regard, some others $[19,20]$ argue that Resilience management improves the likelihood of sustainable paths desirable for development in changing environments where the future is unpredictable and the surprises are likely.

In parallel, the concept of Panarchy aimed to be the representation of the hierarchy between a set of Adaptive Cycles whereby sustainability is the result of the operation of these cycles and the communication between them [21]. A place to capture adaptive nature and evolutionary cycles including those adaptively interlinked across temporal and spatial scales. Thus, Revolt and Remember were defined as the main interactions occurring at different temporal and spatial scales. Thus, when a Panarchy level enters the release $(\Omega)$ phase it can span to higher levels, especially if they are under the conservation stage $(\mathrm{K})$ phase when rigidity and vulnerability are at a maximum and adaptability is low (Rigidity Trap). This is known as the Revolt. In the opposite direction, when upper levels at the conservation stage $(\mathrm{K})$ phase act as the repository of the capital needed for the reorganization $(\alpha)$ phase after the collapse (Poverty Trap) of levels immediately beneath, Remember takes place. It is during these transition phases-from $\Omega$ to $\alpha$, the backloopthat cross-scale interactions have the potential to influence the emergence and potential institutionalization of adaptive governance [22], providing a window of opportunity for change. Thus, the Panarchy is the representation of how a system can take advantage of invention and experimentation, generating opportunities while remaining safe from those processes that, by their nature or exuberance, could reach destabilization [21].

\subsection{Resilience and Panarchy in the Urban Realm. Self-Organization as a Main Issue}

Resilience identifies, understands and provides clear and useful insights from system dynamics that constitute a large potential for urban systems, although tools to bridge and put urban resilience analysis findings into urban planning, economy, and policy realms and practices are needed [3]. It is this Panarchy model of Adaptive Cycle that underpins the evolutionary meaning of Resilience. Resilience from this perspective is understood not as a fixed asset but as a continually changing process, not as a being but as a becoming [23]. In the same way, Davoudi [24] proposes that complexity theory is the epistemological basis of evolutionary resilience and emphasizes the possibility of ruptures and transformations, whereby small-scale changes can amplify and cascade up into major disruptions of perceived stability or normality. Here, resilience is not about bouncing back to where we were, but about the capacity for adaptation and, crucially, 
for transformation. The Panarchy model can offer a powerful narrative with practical implications for a better understanding of the vulnerabilities and windows of opportunity of real estate dynamics. Urban resilience lies in its capacity to adapt and transform itself to meet the needs and aspirations of its citizens, rather than in its ability to return to its pre-crisis form. Some others assume that cities have a cyclical existence of production, growth, waste and shrinkage. So the appearance of vacant land thus signals that the city is just in one stage of this natural cycle [25], implicitly accepting the dynamic nature of the city.

Schlappa's [26] studies of the evolution of the Shrinking Cities embrace the adaptive cycle approach for the assessment of the possible future trajectories. For Herrman [27], Panarchy helps with conceptualizing the dynamics of shrinking cities as it conceptualizes social-ecological systems, such as urban systems, as a hierarchy of adaptive cycles. Changes in lower-order cycles can create the circumstances for change (Revolt) in a higher-order cycle. Further, Marcus [28] and de Balanzo [29] highlight the role of social movements during the backloop as a trigger for urban dynamization at the city scale. Self-organized social momentum during the release $(\Omega)$-reorganization $(\alpha)$ phases within the social subsystem scale-up to the urban scale overflowing the boundaries of the social dimension and impacting the city system.

\subsection{Fath Approach. Navigating the System as a Measure of Resilience}

Between the two, the theoretical framework (Adaptive Cycle theory) on the one side, and the self-organization of social systems as a measure of resilience on the other, Fath's model provides a useful analytical framework to evidence socially-led socio-ecological resilience in the urban realm. According to Fath, self-organization, in terms of the extent to which the system can restructure social networks and develop new organizations from within, appears to be crucial to escape the Vagabond Trap at the $\alpha$-phase. Further, Fath's approach also provides key preparedness features that must be cultivated in each stage of the adaptive cycle to avoid or escape from ailment and traps during the process. The Vagabond Trap and the Dissolution Trap are newly defined, along with the previous Rigidity and Poverty ones, as the system's pathologies or ailments prevent the system from progressing. Fath's framework provides a useful guideline to analyze social response to traps at each stage of the adaptive cycle. Table 1 summarizes Fath's provisions for readiness to successfully navigate the system across pathologies and ailments.

Table 1. Fath's model for the navigation through pathologies and ailments. Adapted from Fath [12].

\begin{tabular}{|c|c|}
\hline Traps-Stage & Preparedness Features \\
\hline \multirow{4}{*}{$\Omega$-stage (Release)-Dissolution trap } & $\begin{array}{l}\text { 1. Reduce fault cascade }(\mathrm{r}) \text { : The ability to prevent crises from spreading throughout the } \\
\text { system through early detection and organizational structure. }\end{array}$ \\
\hline & $\begin{array}{l}\text { 2. Cohesive leadership (K): Key actors that back growth financially and spread information } \\
\text { rapidly. }\end{array}$ \\
\hline & $\begin{array}{l}\text { 3. Maintain vital functions }(\Omega) \text { : Identifying and maintaining functions that are essential to } \\
\text { the continuation of a minimum level of social utility. }\end{array}$ \\
\hline & 4. Improvisation $(\alpha)$ : Suspending prescribed roles in response to immediate needs. \\
\hline \multirow{4}{*}{$\begin{array}{c}\alpha \text {-stage } \\
\text { (Reorganization)-Vagavond trap }\end{array}$} & $\begin{array}{l}\text { 1. Self-organization }(\mathrm{r}) \text { : The extent to which the system can restructure social networks and } \\
\text { develop new organizations from within. }\end{array}$ \\
\hline & $\begin{array}{l}\text { 2. Access to stored capital (K): The access to emergency resources in the form of natural, } \\
\text { built, human, economic, and social capital during and post-crisis. }\end{array}$ \\
\hline & 3. Memory $(\Omega)$ : Remembering both past crisis experiences and past successes. \\
\hline & $\begin{array}{l}\text { 4. Modularity }(\alpha) \text { : Sets of densely connected nodes loosely connected to other subsets of } \\
\text { nodes. }\end{array}$ \\
\hline
\end{tabular}


Table 1. Cont.

\begin{tabular}{|c|c|}
\hline Traps-Stage & Preparedness Features \\
\hline \multirow{4}{*}{ r-stage (growth)-Poverty trap } & $\begin{array}{l}\text { 1. Positive feedbacks (r): A change in a particular variable, process, or signal reinforces } \\
\text { subsequent changes of the same type. }\end{array}$ \\
\hline & $\begin{array}{l}\text { 2. Bilateral information flows (K): Information flowing in both directions of system } \\
\text { hierarchy. }\end{array}$ \\
\hline & $\begin{array}{l}\text { 3. Emergent leadership }(\Omega) \text { : Emergence of and collaboration with organizations not } \\
\text { originally tasked with a particular crisis response. }\end{array}$ \\
\hline & $\begin{array}{l}\text { 4. Adaptive capacity }(\alpha) \text { : Recognizing learning experiences and using the opportunity to } \\
\text { make adjustments to behavior. }\end{array}$ \\
\hline \multirow{4}{*}{$\begin{array}{l}\text { K-stage (Consolidation) - Rigidity } \\
\text { trap }\end{array}$} & 1. Negative feedbacks (r): Structural characteristics that regulate the rate of growth. \\
\hline & $\begin{array}{l}\text { 2. Maintain diversity }(\mathrm{K}) \text { : Diversity in function and response of components and their } \\
\text { relationships. }\end{array}$ \\
\hline & 3. Small-scale disturbances $(\Omega)$ : The frequency and intensity of noncrisis disturbances. \\
\hline & apacity $(\alpha)$ : Stored capital and redundancies within the system. \\
\hline
\end{tabular}

\section{Materials and Methods}

3.1. The Case Study: "CanFugarolas: Workshop of Social and Sustainable Repairs", in Mataró (Barcelona, Spain)

Similar to other cities in the industrial periphery of Barcelona, Mataró (see Figure 1) experienced a large population increase due to the migratory waves of people moving from other regions of Spain from the 1950s to 1990s. In fact, the population of Mataró more than doubled, from 40,000 inhabitants in 1950 to 90,000+ in 1990 (and about 129,661 in 2020). Between 1962 and 1992, there was strong urban growth and expansion owing to its important industrial activity. However, during the 1990s, symptoms of stagnation and obsolescence arose, with industry greatly affected by the post-Olympics crisis and the closure of textile companies, with only a few remaining metallurgical companies [12]. Regarding urban planning, PlaMat77 acted as the regulatory framework at that time, and it was characterized by the extensive growth measures typical of that time along with the densification of the existing urban fabric [30]. Thirty years of growth (1960s-1990s) had formed an incoherent, very dense, disconnected and non-organic city [31]. Subsequently, the city (especially some inner areas) experienced a progressive abandonment together based on-or due to- the relocation of the industrial enclaves of the twentieth century, leading to the proliferation of underutilized factory environments within the consolidated urban fabric. According to Saez [32], urban gaps in Mataro were evident from a concentration of empty buildings in former industrial areas, and social initiatives were revealed as a self-organized, spontaneous response to urban regeneration policies.
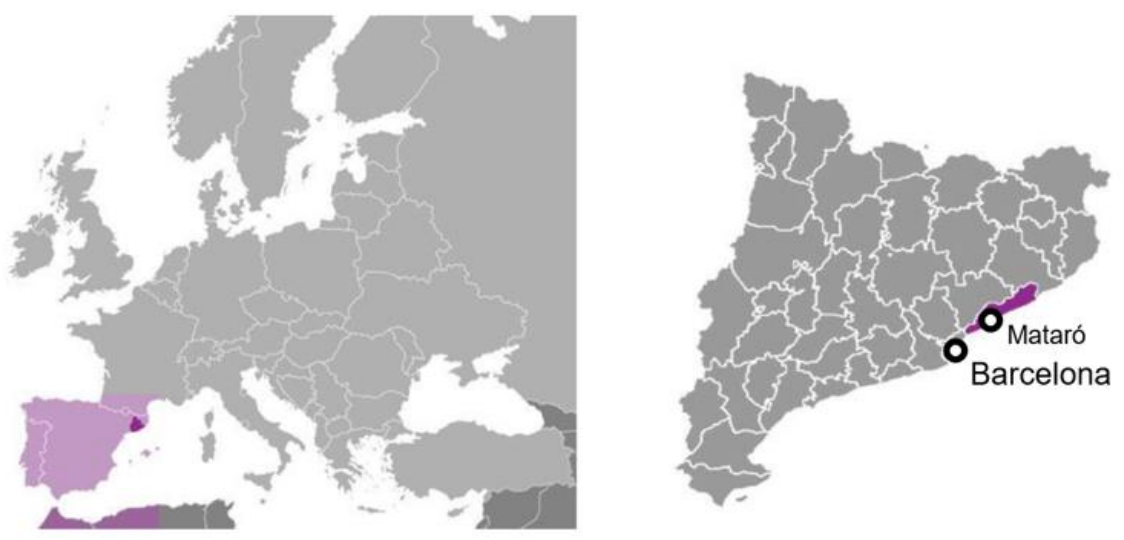

Figure 1. Location of Mataró (left) in southwestern Europe and (right) in Catalonia. 
The CanFugarolas project is based on the reuse of obsolete industrial spaces. In fact, the project is the continuation of the socio-cultural, community-led project led by four local groups (e.g., Cronopis (Mataro, Spain), Taller d'Idees (Mataro, Spain), Estudi I Mig (Mataro, Spain) and Co-Working (Mataro, Spain)). These are all local entities devoted to cultural and artistic socially-based initiatives (a circus company, two media companies, audiovisual production companies and a collective of freelance professional, including architects, graphic designers, researchers and carpenters). Three former industrial buildings in Mataró had previously witnessed the project's birth and evolution before being either demolished or refurbished for other uses, according to the provisions of the urban planning regulatory framework-La Fibra (2006-2008), Can Fàbregas I Caralt (2008-2009) and Can Fàbregas de Paper (2009-2013). In 2013, due to the urgent need to abandon its former site in the industrial warehouse of Can Fàbregas de Paper, a new location was needed and found (see Scheme 1). This exemplifies the evolving and adaptive nature of the project, as well as the social, infrastructural and regulatory interdependency that is addressed below.

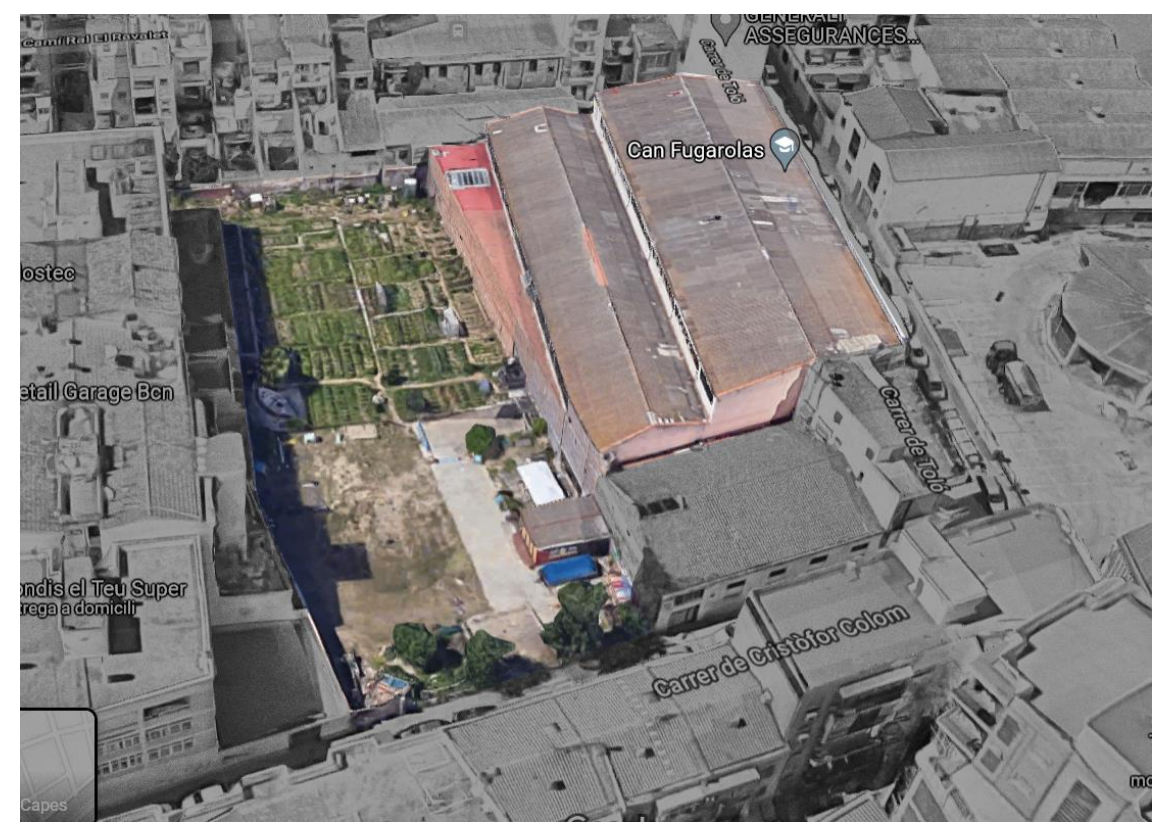

Scheme 1. View of the current emplacement of the Project at its current location in CanFugarolas.

According to their own manifest, the very first aim of the CanFugarolas project was to "create a sustainable multidisciplinary space that encompasses all types of arts, social projects and social, sustainable and/or cultural enterprises" by converting a mechanical repair workshop into a "social, cultural and sustainable repair workshop". As explained below, the building has been progressively adapted and refurbished to meet the needs of the users throughout the refurbishment and renovation of the inner space (see Scheme 2).

At a regulatory level, the CanFugarolas sector (see Figure 2, right) comprises a former $4500 \mathrm{~m}^{2}$ industrial building and a $2155 \mathrm{~m}^{2}$ inner yard. It was defined as a "Remodeling Sector/5-04_Colón-Toló" by the current Master Plan (1996) to "encourage urban improvement ( . . ) or transformation of decayed buildings" through the delimitation of soil for development sectors" and its replacement with new residential areas. The building consists of a multi-story (basement, ground floor, mezzanine, and first floor) structure. It was vacated in 2002 after 33 years in operation as a car-repair workshop; this was its sole purpose from its construction in 1969 (construction file 972/1965) until its closure and abandonment in 2002. Today, the sector is still pending urban development. 


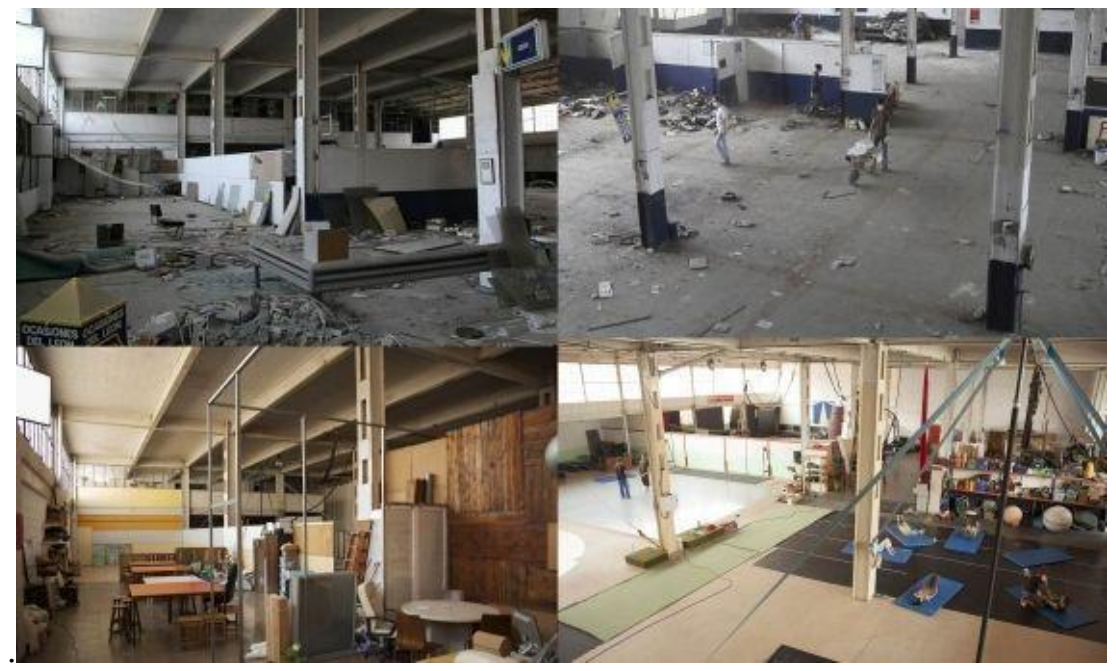

Scheme 2. Comparatives view of the initial (top) and the refurbished (bottom) conditions of the inner spaces of the building.
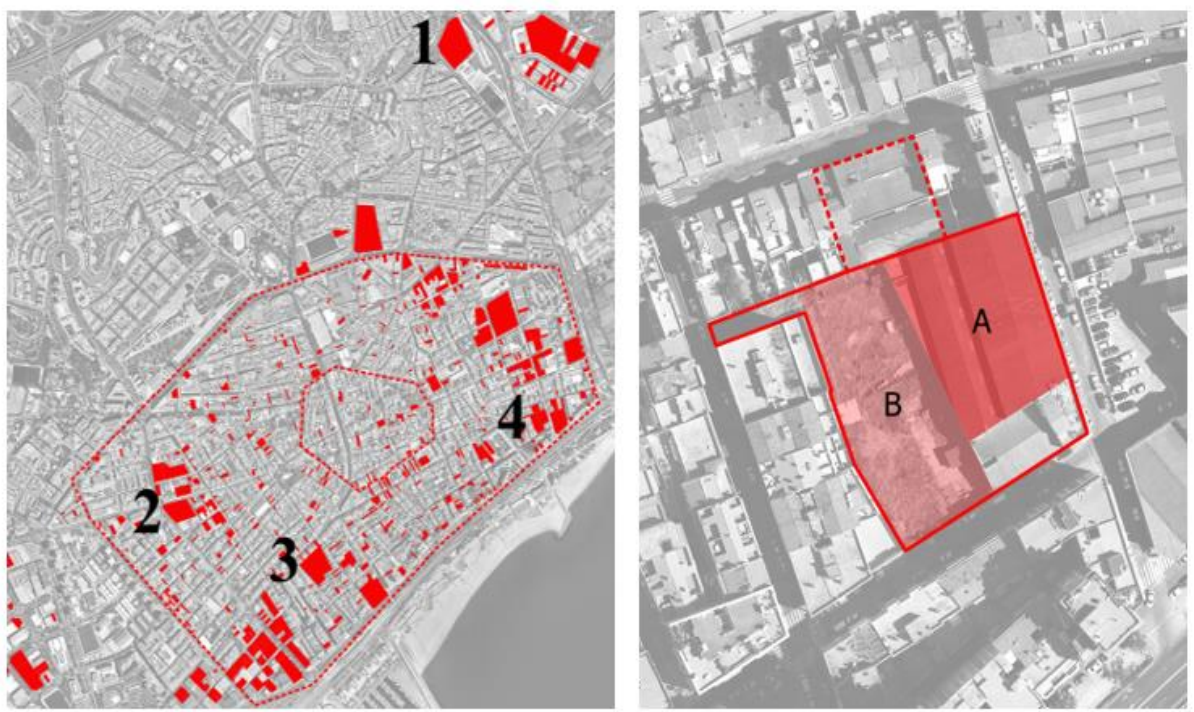

Figure 2. Left: urban gaps in Mataró at the time (2013-2014) the project moved to Can Fugarolas site (4), indicating its former locations (1. La Fibra/2. Can Fabregas i Caralt/3. Can Fabregas de Paper). The Casc Antic (old town) and Plan de Ensanche (Grid Plan, 1878) areas are indicated. Right: delimitation of the urban planning sector (red line) and subsequent extension (dotted red line), as well as the CanFugarolas project area (shadowed in red), identifying the building (A) and the playground (B).

\subsection{Data Collection, Organization, and Analysis}

The article consists of qualitative research that aims to understand the behaviors, processes, practices and relationships not only among people but also at the urban scale, towards a goal of obtaining deeper knowledge of this phenomenon. In line with the constructivist-interpretative perspective (predominant in social sciences), the approach to the case study is mainly based on a vision of reality as the result of the construction, interpretation and experience of people and their interactions among themselves and with other broader social systems [33].

External validity is acquired through various tools as well as from the triangulation of the obtained results [34]. The personal contact between the researchers and the studied group favors a relationship that allows more in-depth knowledge to be gained about what is being studied and that comprises richness and nuances rather than mere data [33]. It is 
therefore an inductive process oriented towards discovery, process and high validity; it is less concerned with generalizability and more concerned with a deeper understanding of the research problem in its unique context [35].

\subsubsection{Data Collection}

The article is based on a mixed method approach that includes a range of tools: interviews, direct observation, participation in the life of the group, collective discussions, analyses of personal documents produced within the group, self-analysis and life-histories. Although generally characterized as qualitative research, it includes quantitative dimensions. According to Spradley's [36] classification, and for the sake of this article and to minimize bias, the observer takes a moderate participation role that maintains a balance between "insider" and "outsider" roles, with a good combination of involvement and necessary detachment to remain objective.

Informal and semi-structured interviews: Seven semi-structured interviews were conducted with the project's representatives (e.g., the promoting and founding entities of the project and municipal planning service representatives). Interviews addressed the following topics: background of the project, main barriers and conflicts related to legal status and planning regulations, the evolution of the project, personal perception of the forecasts and expectations for the future of the project. The interviews were recorded and transcribed for content analysis.

Document review: Relevant documents and grey literature on the three subsystems were reviewed. The social dimension included CanFugarolas' foundational documents, internal functioning docs, as well as the acts of Tronc and General Assembly, as internal decision-making bodies. At the infrastructure dimension, previously published academic and scholar articles and works were consulted. Finally, at the regulatory dimension, current and former Urban Plans, including subsequent modifications, side-planning proposals and regulations, along with winning proposals of architectural contests in the city, were revised.

Questionnaires: Questionnaires for each entity aimed to collect information on the evolution in numbers of the involved participants and entities of the Project (e.g., number of individuals and entities involved). This provided useful information about the Project from 2013 and 2019. In total, 21 questionnaires were collected, covering $100 \%$ of the entities currently (2019) and formerly (2013-2019) involved in the CanFugarolas project.

Participant observation: Participant observation took place between May and December 2018. Two different stages must be distinguished: (1) the first period (May to September 2018), in which the case study was being considered, at which time sporadic contacts (with semi-structured interviews of CanFugarolas representatives) took place; and (2) the second period (October to December 2018) is characterized by direct and permanent contact, as a member of Coworking (participating entity) within the Project. This included attending the Tronc meetings (scheduled assembly), at which internal issues (management, economy, refurbishment, participation... ) were debated, and actions to collectively solve them were discussed.

Web-based tools: Current and historic data accessible from web-based tools (Google Street view) helped to validate and cross data on social-led squatting initiatives and urban voids; these were taken from the study of urban gaps in Mataró.

\subsubsection{Data Analysis}

The methodologies carried out for data collection were not linked to a specific dimension (subsystem) at the outset. This provided a certain degree of triangulation of the information since most of the topics analyzed are fed from more than one methodology. This is expected to improve the robustness of the results. This collection of methodologies provided heterogeneous, dispersed and apparently unconnected information over social evolution, infrastructural support and regulatory framework. This information was first organized upon the scale (large/focal/small) of its implication according to the 
Scalar-Dimensional analysis framework (see Table 2) adapted from the Resilience Alliance Worksheet [37].

Table 2. Scalar-Dimensional framework. Adapted from the Resilience Alliance. Worksheet 1.4 at Assessing Resilience in Social-Ecological Systems: Workbook for Practitioners.

\begin{tabular}{cccc}
\hline Social Subsystem & Infrastructural Subsystem & $\begin{array}{c}\text { Regulatory } \\
\text { Subsystem }\end{array}$ \\
\hline Large scale & $\begin{array}{c}\text { Orchestrated social } \\
\text { initiatives occurring at a } \\
\text { city scale }\end{array}$ & $\begin{array}{c}\text { Regeneration/degradation } \\
\text { at former industrial areas } \\
\text { within the city }\end{array}$ & $\begin{array}{c}\text { Urban regeneration } \\
\text { policies }\end{array}$ \\
\hline $\begin{array}{c}\text { Focal scale } \\
\text { (the project) }\end{array}$ & $\begin{array}{c}\text { CanFugarolas: the project } \\
\text { (independent of physical } \\
\text { emplacement) }\end{array}$ & CanFugarolas: the building & $\begin{array}{c}\text { CanFugarolas: an } \\
\text { urban planning } \\
\text { remodeling sector }\end{array}$ \\
\hline Small scale & $\begin{array}{c}\text { Scattered and dispersed } \\
\text { community-led "actions", } \\
\text { occurring within the city }\end{array}$ & $\begin{array}{c}\text { Scattered regeneration } \\
\text { processes; urban planning } \\
\text { development }\end{array}$ & $\begin{array}{c}\text { Punctual and } \\
\text { sectorial } \\
\text { modifications of } \\
\text { urban planning }\end{array}$ \\
\hline
\end{tabular}

This has relevant implications for the definition of the scale of analysis at each subsystem as well as between subsystems. For instance, whereas the focal scale at the Infrastructural and Regulatory matches the formal and administrative delimitation of the building and the remodeling planning sector, respectively, the focal scale at the social subsystem is defined by the very extension of the actor network, regardless of the successive locations of the project. This lies in the emergence of 'society' as the outcome of heterogeneous relations between actors and artifacts (Murdoch 2006), whereby actors themselves, in networks, are capable of developing meaningful spatial connections, even heterogeneous ones [38].

Subsequently, the chronological and geographical organization of the events allowed a description of the adaptive cycle at each of the subsystems, as well as the identification of cross-scale interactions between the subsystems observed; this provides evidence of Fathbased social resilience as well as social-centered panarchy. Figure 3 shows the progression of the research path, from data collection to the final results. 


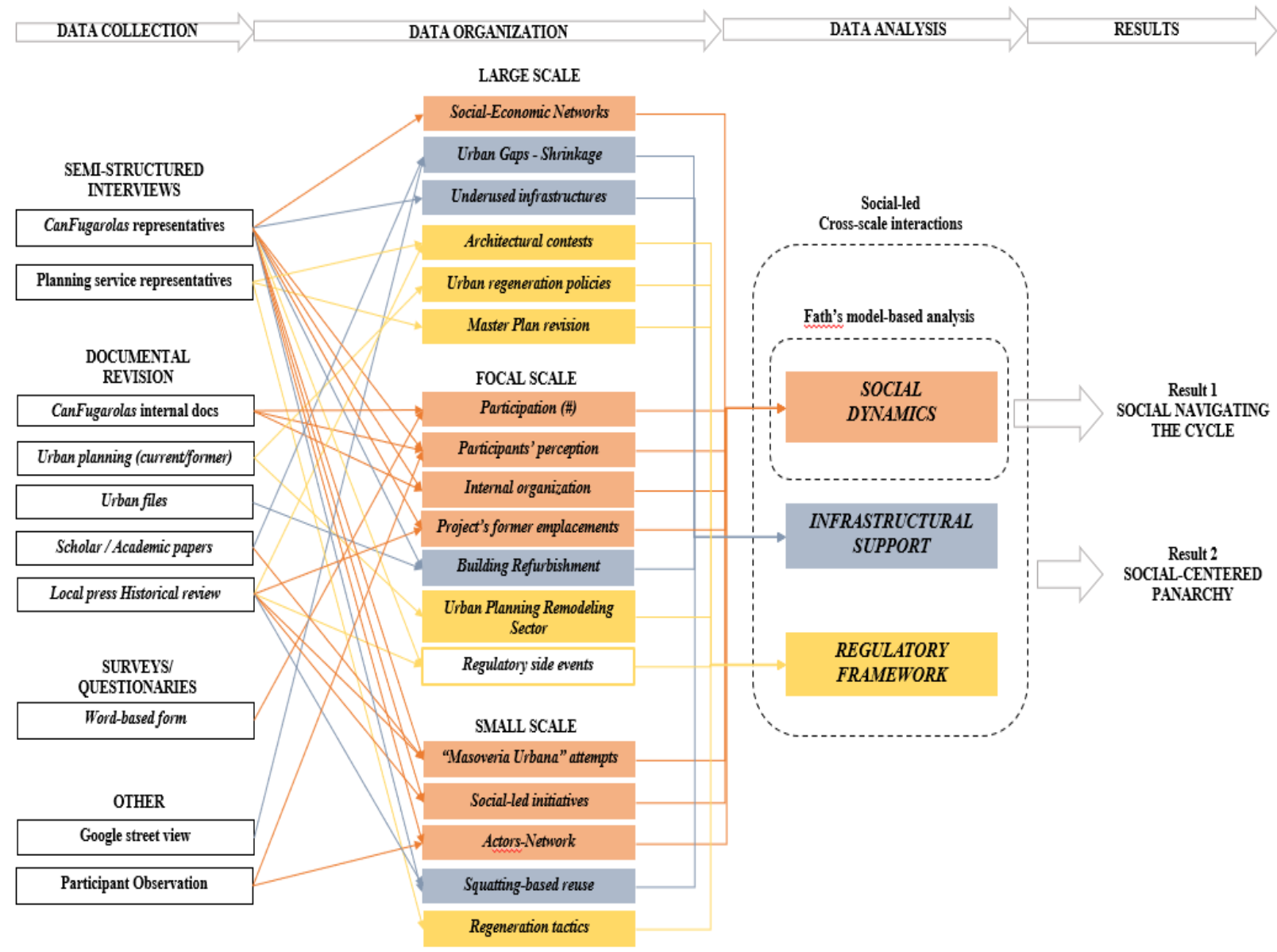

Figure 3. Research Process.

\section{Results}

The results are derived from the principles of the theoretical framework. That is, whereas the Adaptive cycle is the growth-conservation-release-reorganization path that any system follows, and the Panarchy is constituted by the sum of the cross-scale interactions between such adaptive cycles, Revolt and Remember are the mechanisms through which such interactions take place.

\subsection{Running the System. Transiting the Adaptive Cycle}

In the first part of the results, we describe the transition of each urban subsystem, and at the Large/Focal/Small scale, throughout the stages of the adaptive cycle. Based on the model by Fath, the social subsystem (the Project) arises as the only one successfully navigating all stages, evidencing resilience and contrasting with stagnation in the infrastructural and the regulatory ones.

\subsubsection{The Regulatory Subsystem}

At the Large Scale, urban planning and management and urban regeneration particularly is constituted by a set of regulations and ordinances subject to the Municipal Master Plan. The current planning regulatory framework is ruled by the Mataro Master Plan-Pla General de Mataro 1996-(PGM96). Regarding urban regeneration policies, and as explained in its justification chapter, the PGM96 reduced the "extensive character of the growth measures, typical of the moment, and the densification of the existing urban fabric" proposed by the previous PlaMat77. It took the testimony to 'encourage urban improvement (... ) in only waste or transformation of decadent buildings' through the delimitation of "development sectors and of execution in urban soil" which implied their 
demolition and replacement by new residential sectors. However, after a period of great activity in the Real Estate sector (2000-2005), between 2005 and 2008 the city underwent a processive slowdown as a prelude to the subsequent global economic crisis (2008-2015), blocking any regeneration capacity from the private economic agents.

Rigidity Trap self-awareness on urban planning at the Large Scale is evidenced in side attempts at reactivating former industrial premises. Thus, the Pla Especial del Nucli Antic de Mataró (Historic Area Special Urban Planning) in 1998 was a prelude. It described the obsolete industrial buildings as potential repositories for the future regeneration of the city. More recently, the "Modification of the Master Plan for introducing the commercial zones to the urban industrial zones, Clau 2a, (MPG-087)" in 2015 and the "Modification of the Urban planning rules of the Master Plan referring to the regulatory parameters of uses and activities (MPG-089)" in former industrial areas, in 2016, also evidence this. Parallel, successive architecture competitions for Can Cruzate (2005), Muralla d'en Titus (2016), and Impuls de Mataró Centre (2018) deepened the incapacity of "as usual" urban planning to trigger urban regeneration. The latter's call for proposals highlights the "stagnation for the last 10-15 years" and "the stoppage of urban planning spheres of remodeling" as the consequences of said stagnation.

At the Focal Scale, PGM96 defined Can Fugarolas as one such Remodeling Sector (Sector 5-04_Colón-Toló). This rigidly determined the geographical boundaries, the general ordering of building parameters, along with the activities to be guaranteed and allowed within the sector, during the phase of transition as in the moment of its definitive transformation. PGM96 justifies its (the sector's) urban development potential, as "its current industrial location is disassociated from the productive fabric and does not adapt to the characteristic residential sector", describing it as an area of "urban industry (...) with the aim of maintaining them until by initiative or by the process of the company itself is transferred or transformed," trusting, therefore, in economic dynamics to make this transformation process "possible".

However, in the absence of the necessary private initiative-due to macroeconomic crisis - the municipality processed - ex officio-a modification (Modificació Puntual del Pla General/MPG-56) of the Master Plan in 2005 to "greatly expedite the management" for the Can Fugarolas sector. It was explicitly expected that administrative simplification would make the urban development of the area "economically attractive". Again, planning development and urban regeneration relied on economic, administrative, and financial momentum to be executed. However, this deepened the rigidities for the transformation of the sector since it introduced new regulatory elements such as the obligation to annex and rehabilitate the Martorell Batlle i Cia factory to allocate the mandatory reserve for public housing within the sector. Here, Rigidity is also evidence of the fact that, almost 15 years after its approval, the sector is still pending (planned) development.

At the Small scale, pioneering attempts at the implementation of Masoveria Urbana stand. They consisted of a proposal from Associació Dret a Sostre to find a solution to both the reuse of empty residential buildings and the housing issue by means of a contract where the owner assigns the right to use and enjoy the property in exchange for certain repairs or renovations to the property in question, which can be complemented with a more affordable rent than the market price [39]. Indeed, this defined a very attractive and innovative regulatory framework, although only a single contract was signed for the reuse and refurbishment of one commercial premise for two years.

\subsubsection{The Infrastructural Subsystem}

Despite efforts and side attempts from urban planning to overcome stagnation in the urban regeneration process of former industrial environments, the proliferation of urban gaps evidenced renovation policies' failure. According to Saez [32], over urban gaps in Mataro, the geographical concentration of derelict building typologies on three areas of the city is revealed, corresponding with three former industrial areas: Balanzó i Boter, Entorns Biada, and finally the Eixample de Llevant where Can Fugarolas is located. 
The building (Focal scale) was vacated in 2002 because of deindustrialization dynamics. According to the files, during the former period (1963-2002) it was devoted to being a car repair workshop and was not subject to any major formal transformations until its abandonment. Afterwards, Rigidity Trap appears in terms of its incapacity to maintain the former car-repairing activity it was specifically designed for in the face of new planning (PGM96) disposals. Here, specialization of its seminal design became a major obstacle for adaptation. Afterwards, dismantling and the relocation of the facilities and industrial equipment to another location along with more than 10 years of inactivity (2002-2013), irregular use and vandalism actions resulted in impoverishment and the decay (Dissolution Trap) of spatial-formal conditions. Hence, by the time prior to the entrance to the building, the Poverty Trap is evidenced as the system cannot access enough activation energy to reach a state where positive feedback drives growth internally [12].

\subsubsection{The Social Subsystem}

Unlike in the Regulatory and Infrastructural ones, the Social subsystem portrays adaptive behavior, since inner processes enable the system to navigate the cycle despite disturbances and pathologies. As stated above, CanFugarolas-in its current location-is heir to previous self-organized community-led projects performed by the reuse of obsolete industrial spaces. CanFugarolas-borrowing its name from the previous car repair workshop-is the fourth emplacement of the socio-cultural project led by Cronopis (circus company), Taller d'Idees, Estudi I Mig and Co-Working. Three former industrial buildings in Mataró-La Fibra (2006-2008), Can Fàbregas I Caralt (2008-2009) and Can Fàbregas de Paper (2009-2013) - have previously witnessed its birth and evolution before being demolished or refurbished, obliging the Project to move. Thus, in 2013, and due to the urgency of abandoning the old site in the industrial warehouse of Can Fàbregas de Paper, the beginning of a new (current) adaptive cycle was set out.

Thus, in the face of the danger of disappearing (Dissolution Trap), the engagement of the Project's participants to some other social-led initiatives around the city help to keep the social core. Such individuals become a cohesive leadership structure for the next stage since this allows them to maintain, even at the economic level, basic capacities and social functioning and focus their efforts on finding a new location for The Project. During that time, there is no organization, no structure or hierarchy at all, just informal, albeit continuous, contacts. Subsequently, a fast process (October-November 2013) of reorganization takes place, characterized by self-organization capacity to restructure and reactivate the previous social network as the seed for future growth (engagement of new entities) of The Project. Here, Individuals (Active Agents) are the bearers of the stored capital (from K) in the form of personal knowledge and the experience of the previous and parallel initiatives they are involved in. As mentioned before, the existence of a network of social actions all around the city participated in by a set of active agents becomes crucial for reorganization. It is a period for frequent, direct, and informal meetings in the search for a new location that suits the Project's needs, especially those of spatiality (high) for the Cronopis-circus company's performance.

Later, once CanFugarolas (building) is 'entered' (November 2013) as a major step forward and as positive feedback, a first organizational chart arises as the foundation for subsequent growth. Four Working Commissions (Neighborhood, Economic, Internal and External Relationships) are set up and "Tronc" is defined as the collective decision-making body. A meeting schedule (every 15 days) is also established. During that period (October 2013-gen 2014), social organization is still weak in the economic and organizational dimensions. By the end of November 2013, the number of working commissions had increased to seven, including those of Spaces, Energy, and Technical Management. Subsequently (gen 2014-November 2016), expansion and dissemination activities take place both at the neighborhood scale (specific commission for "Neighborhood Relationships" /Open Days/adds campaign) and at city scale and beyond (CanFugarolas website, social networks, press conferences) driving the system forward. Their main slogan is "we want a 
project open to the Havana neighborhood and the city of Mataró". A few months after its proposal, between the end of 2014 and the beginning of 2015, Can Fugarolas' Federation of Entities (Federació d'Entitats de Can Fugarolas) was constituted as the new legal and administrative framework. Therefore, entities participating in the project shall be constituted as associations under the coverage of the Federation. A functioning structure and an administrative and economic hierarchy are thus established. In February 2015, parallel to the increase of entities and individuals involved, the Document for new Collectives (Document de nous Col-lectius) is presented, while in 2016, at the project's peak (21 entities and almost 350 people), the Guide for entities and collectives (Guia per entitats i col-lectius) also appears. These two documents imply a step forward in the implementation of an internal regulatory framework for the acceptance of new projects, the definition of the rules of operation and internal coexistence and participation, and the definition of the economic conditions for participants. They become, therefore, tools for the consolidation (K phase) of the organization, participation, and communication hyper-structure. It is time when, for the first time, some of the projects willing to set up at the factory are rejected (e.g., boat repair in the inner courtyard).

A lack of participation in meetings is revealed by Tronc as one of the main problems for the future of the project. In March 2017 someone states "we do not finish the meeting, we are tired. We are few and we are tired of being few". This is also unveiled due to the interventions during the 2018 Extraordinary Assembly over the future of CanFugarolas. One of the attendants rhetorically asks: "Is it (CanFugarolas) a bubble? Is it just a spark? Are we seeding? Will they do us out?". In response to this (escaping the rigidity trap), new procedures are implemented, such as Tronc extraordinary meetings (Troncs Extraordinaris), when deemed necessary (flexibility), and the General Assembly (Assemblees Generals) was scheduled annually. The need for a manager-facilitator-agitator (GFA) also emerges to encourage both participation and internal communication. Self-awareness of social hyperconnectivity and hyper-structuring is also evidenced in the 2018 Extraordinary Assembly's minutes where the need for a salaried technical commission or even the control of the participation in the Tronc assemblies are argued. In addition, parallel to efforts to maintain and strengthen-centralized-communication channels as well as the involvement of entities within Tronc, decentralized communication between entities emerges. The need for some entities (2017 Tronc's acts) to "act on the fringes" of Tronc, avoiding "too much bureaucracy", is evidenced.

Based on Fath's framework, Table 3 summarizes the successful social response in the face of traps at each stage of the cycle.

Table 3. Social subsystem navigating the Adaptive Cycle. Adapted from Fath (2015).

\begin{tabular}{|c|c|c|}
\hline Traps-Stage & Period & Social Subsystem Response \\
\hline \multirow{4}{*}{$\begin{array}{c}\Omega \text {-stage } \\
\text { (Release)-Dissolution trap }\end{array}$} & \multirow{4}{*}{ September 2013} & $\begin{array}{l}\text { Participation (at the individual level) of some of the actors of the Project } \\
\text { in scattered social initiatives (shadow networks) in the city prevents the } \\
\text { dismemberment of the social capacity at a large scale. }\end{array}$ \\
\hline & & $\begin{array}{l}\text { All the entities taking part of the project in Can Fabregas de Paper } \\
\text { strengthen linkage in the face of its forced abandonment and provide } \\
\text { their financial capacity, even at an individual/personal level, for the } \\
\text { continuation of the project, wherever it is. }\end{array}$ \\
\hline & & $\begin{array}{c}\text { Maintenance of the "usual" activity in view of the notification to leaving } \\
\text { the previous location. }\end{array}$ \\
\hline & & $\begin{array}{l}\text { However, forced leaving of Can Fabregas de Paper makes everyone focus } \\
\text { on finding a new location. }\end{array}$ \\
\hline
\end{tabular}


Table 3. Cont.

\begin{tabular}{|c|c|c|}
\hline Traps-Stage & Period & Social Subsystem Response \\
\hline \multirow{4}{*}{$\begin{array}{l}\alpha \text {-stage (Reorganization)- } \\
\text { Vagavond } \\
\text { trap }\end{array}$} & \multirow{4}{*}{$\begin{array}{l}\text { October-November } \\
2013\end{array}$} & Former Project's entities constitute CanFugarolas' seminal organization \\
\hline & & $\begin{array}{l}\text { Individuals (active agents) from former social-led initiatives participating } \\
\text { the Project become the main capital (knowledge) during reorganization }\end{array}$ \\
\hline & & $\begin{array}{l}\text { The Project's former experiences as a social background in the form of } \\
\text { organizational and administrative/legal memory }\end{array}$ \\
\hline & & $\begin{array}{l}\text { Set of scattered actors-relational networks taking place within the city as } \\
\text { emergent responses to urban regeneration policies (urban gaps) }\end{array}$ \\
\hline \multirow{4}{*}{$\begin{array}{l}\text { r-stage (growth)-Poverty } \\
\text { trap }\end{array}$} & \multirow{4}{*}{ End 2013-Mid 2016} & $\begin{array}{l}\text { Entering Can Fugarolas (the building) implies the access to a new } \\
\text { dimension of possibilities and engagement of new entities to the Project }\end{array}$ \\
\hline & & $\begin{array}{l}\text { Multilateral conversation among actors. Network connections are } \\
\text { established, and trust and dependencies are built. }\end{array}$ \\
\hline & & $\begin{array}{c}\text { Cronopis stands up as the leader as it becomes the spoke-man with to } \\
\text { Municipally and establishes connections to other entities aiming at } \\
\text { participating The Project }\end{array}$ \\
\hline & & $\begin{array}{l}\text { Definition of seminal Structured/Hierarchical functioning rules as } \\
\text { foundational conditions to grow }\end{array}$ \\
\hline \multirow{4}{*}{$\begin{array}{c}\text { K-stage } \\
\text { (Consolidation)-Rigidity } \\
\text { trap }\end{array}$} & \multirow{4}{*}{ Mid 2016-today } & $\begin{array}{l}\text { Inner Regulatory framework to improve communication and } \\
\text { participation channels }\end{array}$ \\
\hline & & $\begin{array}{l}\text { The characteristics of the new proposals are analyzed before allowance to } \\
\text { join the Project. This is deemed to ensure diversity }\end{array}$ \\
\hline & & $\begin{array}{l}\text { Parallel communication channels (in the fringes) and alternatives to } \\
\text { original designed functioning of the building (new entrance) appear }\end{array}$ \\
\hline & & $\begin{array}{l}\text { No personal assignment of positions and responsibilities (flexible } \\
\text { hierarchy). Set up of social networks at larger scales }\end{array}$ \\
\hline
\end{tabular}

\subsection{Community Driving Urban System. The Social-Centered Panarchy}

Under the Scalar-Dimensional framework defined by the Resilience Alliance, the second part is devoted to analyzing the social-centered Panarchy, where the community (social subsystem) becomes both the receiver and trigger of urban dynamics. Thus, Remember (Figure 4) and Revolt (Figure 5) mechanisms are identified and characterized as the swaying social-centered urban Panarchy. In the first place, Remember takes place when capital accumulated at higher and slower levels during the Conservation stages (K-phase) becomes the source for the reorganization ( $\alpha$-phase) at the lower ones. In the other way around, Revolt occurs when the beginning of the Release ( $\Omega$-stage) at lower subsystems scale-up, triggering the vulnerable conservative equilibrium (K-phase) of the upper subsystems.

\subsubsection{Remember. Social Subsystem as the Sink of the Urban System}

As advanced, CanFugarolas' Social Subsystem is heir to previous (Small Scale) selforganized and community-led actions (shadow network). However, apart from the previous emplacements, the Project also benefits (Rm1 in Figure 4) from scattered social-led initiatives (shadow networks) all over the city (e.g., squatting at La Fibra (2005), which subsequently became the first location of The Project-Secopal (2008), and Café del Mar (1998) or Masoveria Urbana attempts in early 2000). Such Remembering provides the Project with resources from the integration of capital (in the form of individuals' knowledge, collective experience, and germinal and weak organizational structure) accumulated at lower scales. CanFugarolas also benefits from several, albeit micro, economic, cultural, and educational grassroots-led entrepreneurial initiatives (e.g., existing activities moving to CanFugarolas after it is set up) throughout the city —and region-that find in CanFugarolas an ideal ground to land, network and grow. 


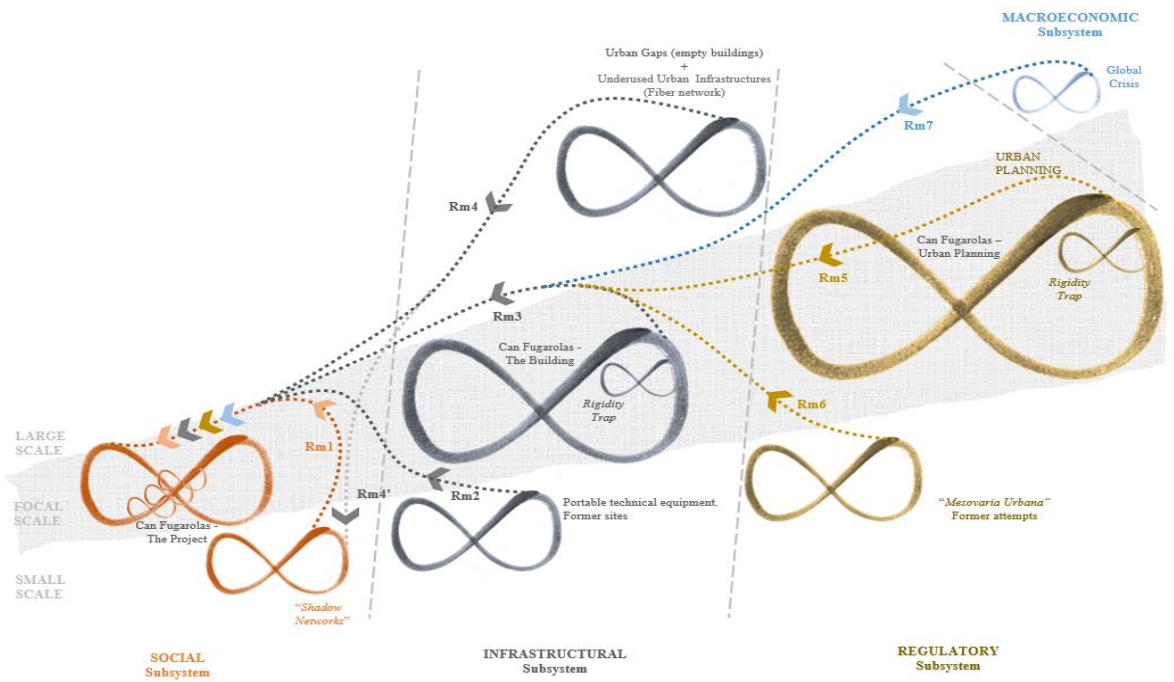

Figure 4. Social-centered Panarchy: Remember. Social as Urban Sink.

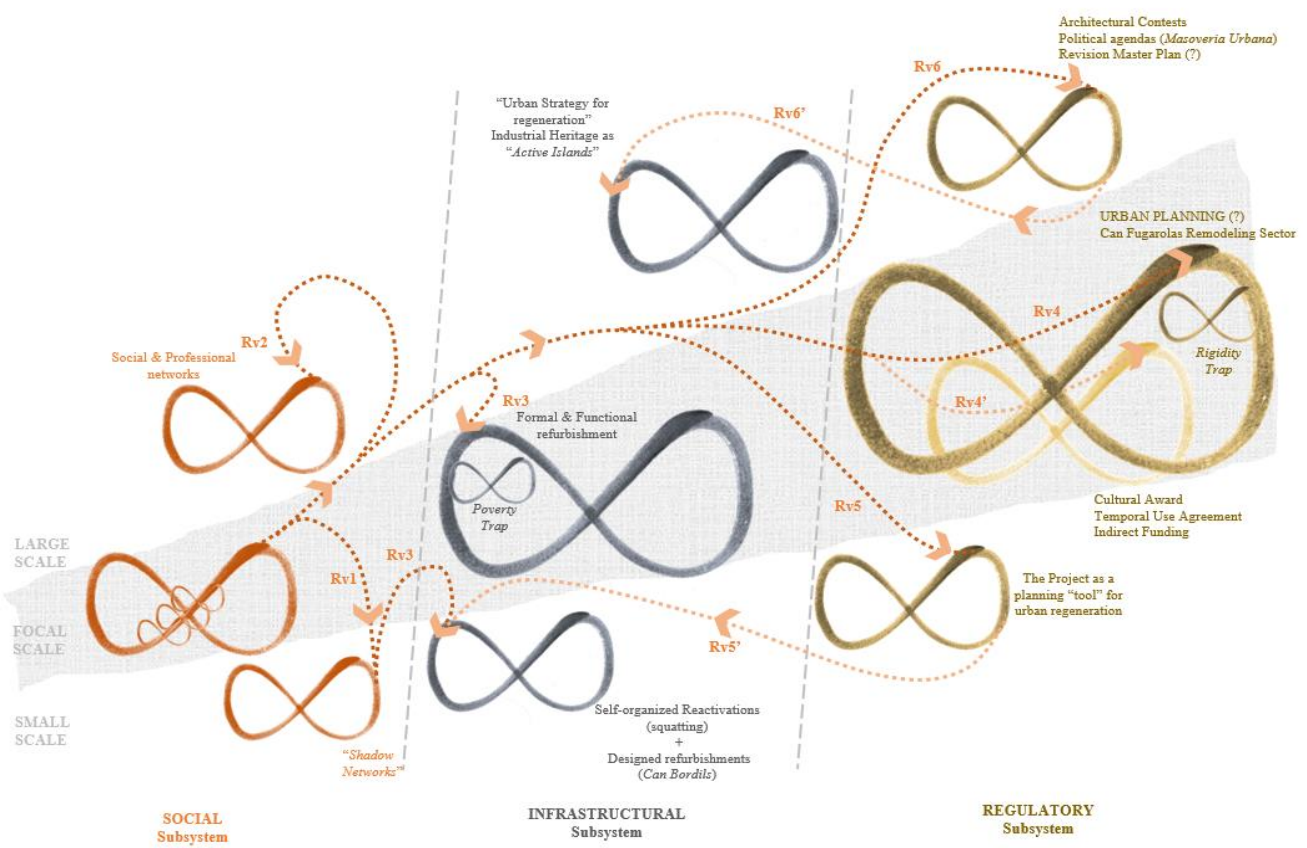

Figure 5. Social-centered Panarchy: Revolt. Social as Urban Trigger.

At a cross-dimensional level, rehabilitation and refurbishment work on previous locations of the Project, provide (Rm2 in Figure 4) portable technical equipment for a quicker reactivation at the new emplacement. Similarly, urban gaps-evidencing stagnation at the Infrastructural Subsystem-become (Rm3 in Figure 4) the formal resource during reorganization at the Social Subsystem. Indeed, space appears as a vital resource for the development of social initiative. As acknowledged during the interviews, the spatial conditions (such as height) at the CanFugarolas building mainly determined its suitability to host the Project. Beyond formal considerations, the Project also aims at defining itself as a social reformulation of its former industrial activity, from a "Vehicle Repair Workshop" to the new "Social Repair Workshop". This emphasizes its seminal will for a social reformulation, also at the semantic level. At the large scale, the Infrastructural System has systematically provided resources to the Social in the form of derelict industrial buildings, both at the Focal scale (Rm4 in Figure 4 ) and as a resource for small scale (squatting) initiatives ( $\mathrm{Rm} 4^{\prime}$ in Figure 4). The Project also takes advantage of external underused urban infrastructure (e.g., Bankia optical-fiber network) in the area for its internal (inner computer network) 
operation. Again, the infrastructural "waste" derived from the economic and financial stoppage (K phase) becomes a source for social growth ( $\alpha$ phase).

At the same time, experience and knowledge accumulated in the Regulatory Subsystem are also transferred. In this regard, stagnation in the Regulatory system (urban planning policies) provides (RM5 in Figure 4) a window of opportunity for social innovation. (e.g., participants and attendees to the Project register as partners, not as customers, to overcome legal limitations that arose from the unaffordability of fireproofing the metal structure). This matches Chaffin's [22] conception of the Window of Opportunity as the beginnings of an answer and the capacity generated by cross-scale interactions during key periods of crisis to change the status quo. Further regulatory and bureaucratic background of Masoveria Urbana attempts at a small scale also become the capital assumed (RM6 in Figure 4) during the reorganization process of the community thanks to the integration of human capital (individuals).

Beyond the scope of the paper, stagnation, even at a higher (macro-economic) level, becomes a crucial factor for the progression at the Social. The building owner's financial problems (and possible foreclosure) makes (RM7 in Figure 4) the signature of the Masoveria Urbana agreement possible. It freed the tax obligations of the owner in exchange for devoting the entire amount of the rent to the formal refurbishment of the building, which in turn benefited the physical dimension.

\subsubsection{Revolt. Social Subsystem as the Trigger of the Urban System}

In the opposite direction, social dynamism pushes urban dynamics both in terms of intra-scale (Focal to Focal) and cross-scale (Focal to Large/Small) interactions. Critical shifts in the (Social) cycle scale-up shift the vulnerable stage of a longer and slower cycle (Holling 2002).

Thus, throughout the life of the Project, CanFugarolas has run (Rv1 in Figure 5) as a platform for the creation, consolidation, interaction and/or growth of many other smallscale community-led initiatives. Apart from the four founding entities, 21 collectives have participated in the Project. At a large scale (Rv2 in Figure 5), this allowed the emergence and consolidation of an informal entrepreneurial and creative social microcosm. This comprises both CanFugarolas participant entities that moved afterwards, professional or technical suppliers, and artistic collaborations (temporary stays) within the Project's facilities, in the form of a collaborative network.

Social navigating also allows the formal reorganization at the Infrastructural Subsystem (e.g., refurbishment of the physical support). Indeed, the progression at the Social Subsystem translates into a formal and functional reactivation of misused infrastructures, both at the Focal (Rv3 in Figure 5) scale (CanFugarolas' building) and Small (Rv3' in Fig5) scales (squatting). Here, two community-led crowdfunding campaigns appear as an expression of social innovation capacity for urban progression.

Furthermore, regarding Social to Regulatory interactions at the Focal scale, to date, social momentum has not succeeded in modifying (Rv4 in Figure 5) urban planning provisions for the CanFugarolas Remodeling Sector. However, relevant unexpected side effects $\left(\mathrm{Rv} 4^{\prime}\right.$ in Figure 5) are unveiled, both at the Focal, Small and Large scales of the Regulatory subsystem as transformative seeds for the future. The signature of a Masoveria Urbana agreement for the refurbishment works in the building and the resulting provisional license granted by the City Council are of major importance for providing legal coverage and administrative stability to the Project. Besides this, in the cultural sphere, acknowledgment from the municipality in the form of the 'Premis Cultura Mataró' (City Council cultural awards) in 2016 of the CanFugarolas Project as "an example of cooperation, integration, self-management, and creativity", as well as the inclusion of Cronopis in the schedule of the World Circus Day (2018), resulting in "indirect" funding, also highlight this transformative capacity. This reinforces the former agreement (2008) between Cronopis and the City Council of Mataró (Municipal Institute of Cultural Action-IMAC) for the temporary use of the CanFabregas de Paper building, before moving to CanFugarolas. 
Moreover, the will to use the CanFugarolas project as a "tool" for urban regeneration is revealed during the interview with representatives of the Municipality Planning Service in Mataró. This is evidenced by the aim to reallocate the Project (Rv5 in Figure 5) in another derelict industrial premise (Can Bordils) as a planned mechanism for the recovery of the industrial heritage (Rv5 ${ }^{\prime}$ in Figure 5) at a small scale.

At a large scale (Rv6 in Figure 5), many modifications of the PGM96 were made, explicitly expressing the will to reactivate inner industrial fabrics. Such a shift on urban planning policies crystallizes the regulations for the architectural contest in the face of "stagnation for the last 10-15 years" and " the stoppage of urban planning spheres of remodeling", along with the kick-off of previous studies before the modification of the Master Plan. Further, the integration of Masoveria Urbana policies into the program of some political parties (En Comú Podem Mataró-2019 Elections) also evidences the transformative seed of the Project. New perspectives on urban regeneration policies appear in the winning proposal. Unlike the old urban planning approaches, former industrial areas (Rv7 in Figure 5) are deemed "Active Islands ( ... ) to provide urban activity in the form of work, trade, equipment or housing".

\section{Conclusions and Discussion}

This study identifies and describes urban evolutionary dynamics along the adaptive cycle of the conservation-release-reorganization-growth stages and spatial-temporal interactions (panarchy) that take place within and across social, infrastructural and regulatory subsystems as constitutents of urban system dynamics.

A major conclusion of this work is that community-led initiatives (based on the CanFugarolas project) can be crucial for urban resilience. We used the adaptive cycle and panarchy heuristics to perform a self-organized social-centered analysis of the urban regeneration process (to our knowledge, for the first time). This revealed that the role of grassroots initiatives in the social subsystem is the core of urban dynamics and adaptability. Such initiatives act both as collectors (e.g., urban sink) and promoters (e.g., urban trigger) for urban reactivation in the face of stagnation at the regulatory (e.g., urban regeneration policies) and infrastructural (e.g., urban voids) levels. Our results support our initial research question, allowing us to conclude that self-organized, community-led processes enable the progression of the system, and therefore enable the socio-ecological resilience of the entire (urban) system.

Considering resilience to be the ability to navigate successfully through each stage of the cycle, the social subsystems (see Table 3) portray the capacity to overcome social ailments and traps while going through the adaptive cycle. CanFugarolas' actor network (at the focal scale) shows the ability to interact with social initiatives at both small and large, and temporal and spatial scales, which allows the project to progress. In Fath's terms, social dynamics successfully overcome disturbances, thereby keeping crises under the threshold and avoiding dissolution. This provides the project with enough capital, resources, leadership, flexibility and innovation despite being faced with successive obstacles. While doing so, community overcomes the physical and administrative boundaries of the building and/or the urban planning sector.

Further, we point out the inner and cross-scale interactions that are socially-driven (e.g., social-centered panarchy) in the urban system. Here, social actions are revealed as both an urban sink and an urban trigger through "remember and revolt" mechanisms, whereby the community, in the form of an actor network, acts as the catalyzer of regeneration dynamics and hence for urban resilience, also at the city scale. Thus, the social actor works on the one side to gather sources and capital accumulated at infrastructural and regulatory subsystems during rigidity stages, and on the other, to push forward both the infrastructural and the regulatory stages. In doing so, society allows the urban system to seize windows of opportunity that appear due to malfunctioning and stoppage during the backloop in urban subsystems. According to the complex nature of urban systems, transformative capacity is expressed both in a direct way (formal refurbishment of the 
infrastructural subsystem) and through unexpected side transformative seeds at different scales and dimensions of the regulatory framework.

Without claiming to establish a general predictive or quantitative general model, we believe that this study provides a deeper understanding of the role of self-organized, community-led initiatives for the functioning and progression - and hence resilience-of the urban system. Our results reinforce previous approaches that conclude that social movements are leading urban regeneration dynamics during release and reorganization processes (backloop). However, discouraging statements collected during interviews or extracted from internal documents such as, "Is it (CanFugarolas) a bubble? Is it just a spark? Are we seeding? Will they do us out?" or "we do not finish the meeting, we are tired. We are few and we are tired of being few," along with the decline of participants observed since 2016, denote a certain degree of stagnation of the social dynamics. In parallel, events such as the opening of new independent access for the upper floors and statements, such as "act on the fringes," extracted from the Tronc minutes, hint at the beginning of new internal reorganization processes. Clarifying whether this is the case or not would require an updated analysis of the case study, which would need to especially consider the impact of COVID-19 at the social level. Some issues appear to be crucial for future research on this, including: (i) geographic considerations (boundaries) of self-organized, community-led initiatives as a measure of their true urban impact; (ii) analysis of actor networks' properties, to characterize active agents as core support for self-organization (similar to approaches taken in ecological communities), and (iii) temporality of social-led initiatives in relation to urban planning. Finally, this study also revealed (vi) the relevance of the built stock as the physical support for social performance. Further studies should also address the analysis of the formal conditions of the infrastructural subsystem, at the architectural level, as a main issue for subsequent social development.

Author Contributions: Conceptualization, D.S.U. and R.d.B.J.; Data curation, D.S.U. and E.R.; Formal analysis, D.S.U.; Funding acquisition, D.S.U.; Investigation, D.S.U.; Methodology, D.S.U. and E.R.; Project administration, D.S.U.; Resources, D.S.U.; Software, D.S.U.; Supervision, R.d.B.J., P.F. and P.G.-A.; Validation, E.R., R.d.B.J., P.F. and P.G.-A.; Writing—original draft, D.S.U.; Writing—review \& editing, D.S.U., E.R. and R.d.B.J. All authors have read and agreed to the published version of the manuscript.

Funding: This research was funded by the Agència de Gestió d'Ajuts Universitaris i de Recerca. Gerelatitat de Catalunya. Grant number 2019 FI_B 00760.

Informed Consent Statement: Informed consent was obtained from all subjects involved in the study.

Data Availability Statement: The data that support the findings of this study are available from the corresponding author, [DS], upon reasonable request.

Conflicts of Interest: The authors declare no conflict of interest.

\section{References}

1. Berkes, F.; Kislalioglu, M.; Folke, C.; Gadgil, M. Minireviews: Exploring the Basic Ecological Unit: Ecosystem-like Concepts in Traditional Societies. Ecosystems 1998, 1, 409-415. [CrossRef]

2. Wilkinson, C.; Porter, L.; Colding, J. Metropolitan planning and resilience thinking: A practitioner's perspective Who owns the sustainable city? Crit. Plan. 2010, 17, 2-20.

3. Chelleri, L. From the «Resilient City» to Urban Resilience. A review essay on understanding and integrating the resilience perspective for urban systems. Doc. D'anàlisi Geogràfica 2012, 58, 287. [CrossRef]

4. Masnavi, M.R.; Gharai, F.; Hajibandeh, M. Exploring urban resilience thinking for its application in urban planning: A review of literature. Int. J. Environ. Sci. Technol. 2019, 16, 567-582. [CrossRef]

5. Hassler, U.; Kohler, N. Resilience in the built environment. Build. Res. Inf. 2014, 42, 119-129. [CrossRef]

6. Kohler, N.; Hassler, U. The building stock as a research object. Build. Res. Inf. 2002, 30, 226-236. [CrossRef]

7. Boonstra, B.; Boelens, L. Self-organization in urban development: Towards a new perspective on spatial planning. Urban Res. Pract. 2011, 4, 99-122. [CrossRef]

8. Portugali, J. Self-Organization and the City; Springer Series in Synergetics; Springer: Berlin/Heidelberg, Germany, 2000; ISBN 978-3-642-08481-2. 
9. Pereira, L.M.; Bennett, E.; Biggs, R.; Peterson, G.; McPhearson, T.; Norström, A.; Olsson, P.; Preiser, R.; Raudsepp-Hearne, C.; Vervoort, J. City Research Online - Seeds of the Future in the Present: Exploring Pathways for Navigating Towards "Good" Anthropocenes. In Urban Planet: Knowledge towards Sustainable Cities; Elmqvist, T., Bai, X., Frantzeskaki, N., Griffith, C., Maddox, D., McPhearson, T., Parnell, S., Romero-Lankao, P., Simone, D., Watkins, M., Eds.; Cambridge University Press: Cambridge, UK, 2018; pp. 327-350. ISBN 9781316647554.

10. Scott, J.C. Seeing Like a State: How Certain Schemes to Improve the Human Condition Have Failed; Yale University Press: London, UK, 1998; ISBN 0300078153.

11. Holling, C.S.; Meffe, G.K. Command and Control and the Pathology of Natural Resource Management. Conserv. Biol. 1996, 10, 328-337. [CrossRef]

12. Fath, B.D.; Dean, C.A.; Katzmair, H. Navigating the adaptive cycle: An approach to managing the resilience of social systems. Ecol. Soc. 2015, 20, 24. [CrossRef]

13. Holling, C.S. Resilience and stability of ecological systems. Annu. Rev. Ecol. Syst. 1973, 4, 1-23. [CrossRef]

14. Gunderson, L.H.; Holling, C.S. Panarchy: Understanding Transformations in Human and Natural Systems; Island Press: Washington, DC, USA, 2002; ISBN 1559638575.

15. Holling, C.S. The Resilience of Terrestrial Ecosystems: Local Surprise and Global Change. Sustain. Dev. Biosph. 1986, 14, $292-317$.

16. Levin, S.A. Ecosystems and the Biosphere as Complex Adaptive Systems. Ecosystems 1998, 1, 431-436. [CrossRef]

17. Berkes, F.; Colding, J.; Folke, C. Navigating Social-Ecological Systems: Building Resilience for Complexity and Change; Cambridge University Press: Cambridge, UK, 2003; ISBN 0521815924.

18. Smit, B.; Wandel, J. Adaptation, adaptive capacity and vulnerability. Glob. Environ. Chang. 2006, 16, 282-292. [CrossRef]

19. Folke, C.; Carpenter, S.; Walker, B.; Scheffer, M.; Elmqvist, T.; Gunderson, L.H.; Holling, C.S. Regime Shifts, Resilience, and Biodiversity in Ecosystem Management. Annu. Rev. Ecol. Evol. Syst. 2004, 35, 557-581. [CrossRef]

20. Adger, W.N.; Arnell, N.W.; Tompkins, E.L. Successful adaptation to climate change across scales. Glob. Environ. Chang. 2005, 15, 77-86. [CrossRef]

21. Holling, C.S. Understanding the Complexity of Economic, Ecological, and Social Systems. Ecosystems 2001, 4, 390-405. [CrossRef]

22. Chaffin, B.C.; Gunderson, L.H. Emergence, institutionalization and renewal: Rhythms of adaptive governance in complex social-ecological systems. J. Environ. Manage. 2016, 165, 81-87. [CrossRef] [PubMed]

23. Davoudi, S. Resilience: A Bridging Concept or a Dead End? Plan. Theory Pract. 2012, 13, 299-333. [CrossRef]

24. Davoudi, S. Just Resilience. City Community 2018, 17, 3-7. [CrossRef]

25. Németh, J.; Langhorst, J. Rethinking urban transformation: Temporary uses for vacant land. Cities 2014, 40, 143-150. [CrossRef]

26. Schlappa, H.; Neill, W.B.V. From Crisis to Choice: Re-Imagining the Future in Shrinking Cities; University of Hertfordshire: Hatfield, UK, 2013; Available online: https:/ / uhra.herts.ac.uk/handle/2299/19120 (accessed on 1 November 2021).

27. Herrmann, D.; Shuster, W.; Mayer, A.; Garmestani, A. Sustainability for Shrinking Cities. Sustainability 2016, 8, 911. [CrossRef]

28. Marcus, L.; Colding, J. Toward an integrated theory of spatial morphology and resilient urban systems. Ecol. Soc. 2014, 19, 55. [CrossRef]

29. de Balanzó, R.; Rodríguez-Planas, N. Crisis and reorganization in urban dynamics: The Barcelona, Spain, case study. Ecol. Soc. 2018, 23, 6. [CrossRef]

30. Hosta, M.; Jornet, S. El model territorial en la revisió del Pla General de Mataró. Papers de la Regió Metropolitana de Barcelona. 1995, $23,61-78$.

31. Salicru, M. El Creixement Urbà de Mataró (1962-1992). 1993. Available online: https:/ /www.raco.cat/index.php/FullsMASMM/ article/download/115965/146567 (accessed on 1 November 2021).

32. Saez, D. Resiliència Urbana. Una Aproximació a Les Dinàmiques de la Ciutat. Els Buits Urbans de Mataró. 2014. Available online: https: / / upcommons.upc.edu/handle/2099.1/25062 (accessed on 1 November 2021).

33. Tuli, F. The Basis of Distinction Between Qualitative and Quantitative Research in Social Science: Reflection on Ontological, Epistemological and Methodological Perspectives. Ethiop. J. Educ. Sci. 2010, 6, 97-108. [CrossRef]

34. Ibáñez-Alonso, J. Más Allá de la Sociología. El Grupo de Discusión: Técnica y Crífica. 1979. Available online: https://www. sigloxxieditores.com/libro/mas-alla-de-la-sociologia-el-grupo-de-discusion-teoria-y-critica_16978/ (accessed on 1 November 2021).

35. Ulin, P.R.; Robinson, E.T.; Tolley, E.E. Qualitative Methods in Public Health: A Field Guide for Applied Research. Med. Sci. Sports Exerc. 2005, 37, 1249. [CrossRef]

36. Spradley, J.P. Participant Observation. Orlando, Florida: Holt, Rinehard and Winston; Waveland Press: Long Grove, IL, USA, 1980.

37. Resilience Alliance. Assessing Resilience in Social-Ecological Systems: Workbook for Practitioners. Version 2.0. 2010. Available online: https: / / www.resalliance.org/resilience-assessment (accessed on 1 November 2021).

38. Boelens, L. The Urban Connection: An Actor-Relational Approach to Urban Planning; 010 Publishers: Rotterdam, The Netherlands, 2009; ISBN 9064507066.

39. González, R.; Martí, M.; Peláez, L.; Barranco, O.; Brunet, D.; Gomà, R. Joventut, Okupació i Polítiques Públiques a Catalunya; Generalitat de Catalunya: Barcelona, Spain, 2003. 